\title{
sciendo
}

\section{Public procurement in Romania: environment, stakeholders and critical success factors}

\author{
Ionel PREDA \\ Bucharest University of Economic Studies, Bucharest, Romania \\ predaionel4@gmail.com
}

\begin{abstract}
Public procurement represents the most important link between the public administration and the economy of a state, through which governments buy annually very high value products, works or services. Knowing the characteristics of the environment, critical success factors and stakeholders is of great importance because these are the three main elements that contribute to the award of public procurement contracts and the efficient spending of budgetary funds. The research presents an analysis of the specialized literature, the main statistical data from the official public procurement reports and identifies the most important characteristics of the environment in which public procurement takes place in Romania, the stakeholders and the critical success factors in this field.
\end{abstract}

Keywords: public procurement, environment, stakeholders, critical success factors, e-procurement.

\section{Introduction}

Public procurement is essential for the achievement of government objectives, with large amounts spent. At the level of the European Union, the budget for the period $2014-2020$ is 908 billion euros (EC - European Council, 2013), public procurement representing about 16\% of the EU GDP, while for the period 2021-2027 it is estimated a budget of 1,275 billion euros.

In Romania, the amounts allocated to public procurement represent about $8 \%$ of GDP. In order to highlight the importance of the field of public procurement and the size of the amounts spent, we mention that in 2018 procurement procedures were finalised with a total of the estimated values of 59.927.100 thousand lei, which means about 8.9 billion euros (ANAP - Romanian National Agency for Public Procurement, 2019).

The number and value of public procurement contracts awarded in 2018 in Romania are presented in Table 1.

Table 1. The number and value of the public procurement contracts according to the type of procedure

\begin{tabular}{|c|c|c|c|}
\hline Type of procedure & $\begin{array}{c}\text { Number of } \\
\text { contracts }\end{array}$ & $\begin{array}{c}\text { Awarded value } \\
\text { (thousands of lei) }\end{array}$ & $\begin{array}{c}\text { The weight from the } \\
\text { total awarded value }\end{array}$ \\
\hline Open bid & 8,480 & $16,809,037.12$ & $39.56 \%$ \\
\hline Accelerated open bid & 71 & $30,040.57$ & $0.07 \%$ \\
\hline Restricted bid & 13 & $102,796.39$ & $0.24 \%$ \\
\hline Competitive negotiation & 26 & $974,709.93$ & $0.01 \%$ \\
\hline Competitive dialogue & 1 & 393.97 & $0 \%$ \\
\hline Simplified procedure & 20,478 & $24,567,230.52$ & $57.83 \%$ \\
\hline Total & $\mathbf{2 9 , 0 6 9}$ & $\mathbf{4 2 , 4 8 4 , 2 0 8 . 4 9}$ & $\mathbf{1 0 0 \%}$ \\
\hline
\end{tabular}

Source: (ANAP, 2019)

Although policymakers and governments have paid close attention to public procurement reforms, this area has been and is a neglected area of research and education (Thai, 2001).

Knowing the environment, the stakeholders and identifying the critical success factors in the field of public procurement in Romania is very important because these are the three 
most important elements that contribute to the successful award of public procurement contracts.

\section{Literature review}

\section{The environment in which public procurement takes place}

The effectiveness is the main objective of public procurement, which means the provision by the public sector of better products and services at the lowest possible price (Man et al., 2014).

NASPO (1999) considers that the environment of public procurement in the USA is determined by the action of several powerful forces, including: the increasingly dynamic and diversified market, continuous pressure to reduce staff and / or number of procurements, globalization of economies and markets, explosion of information technology and increased demand for services.

Given these forces, US public procurement reform was mainly based on measures to reduce the number of regulations in the field and decentralization. Winter Commision (1993) made a series of recommendations regarding the reform of the public procurement system: adapting procurement processes and procedures so that they keep pace with the new technologies, emphasizing the quality and results of the procurements in comparison with their cost by introducing incentives for the quality products / services and penalties for the inferior quality, implementation of a policy for small value procurements based on a single signature by allowing employees to make small procurements without the need for approvals and reducing the number of documents and justifications.

Also, US procurement reform was also based on the implementation and use of electronic procurement that accelerated the procurement process (MacManus, 1996) and the introduction into use of procurement cards that reduced administrative costs (Coggburn, 2003).

\section{Stakeholders involved in the public procurement process}

Because the management of public procurement procedures includes the involvement of a significant number of internal and external stakeholders (contracting authorities, beneficiaries, suppliers, providers, consultants, sponsors etc) their importance cannot be underestimated (Grigorescu et al., 2019; Vaidya, Sajeev \& Callender, 2006).

Public procurement must balance a number of different interests. The first is the interest of the public organization to buy the products and services it needs. At the same time, the suppliers have the interest to continue the activity of the companies and to make profit for their own stakeholders. These interests are called primary interests. These interests exist in both the public and private sectors. Secondary interests are those interests that go beyond the contract and exist for both public institutions and suppliers. For suppliers (sellers), these interests can be: increasing market share, gaining experience, creating a customer portfolio, etc. For public institutions (buyers) these interests can be the stimulation of innovation and the creation of new jobs (Telgen et al., 2012).

Based of the analyzes conducted by Veeke, (1992) and Hartland et al. (2006), Telger et al. (2012) identified seven elements common to public procurement, regardless of the country in which they are carried out: the supply and delivery of products and services, compliance with existing legislation / regulations, the efficient use of public funds, responsibility, added value, supporting government policy objectives, meeting government goals (creating new jobs, developing industry, supporting small and medium-sized 
entreprises, stimulating innovation, promoting sustainability and the procurement of green products / services).

\section{Critical success factors for public procurement}

The analysis of critical success factors (CSF) for public procurement has been addressed in the literature by several authors. Critical success factors are a management tool that analyzes the essential elements necessary to achieve the objectives of the procurement processes, namely the efficient procurement, on time and under full legality of the products, services or works needed by a contracting authority.

Critical success factors (CSF) have been analyzed in detail because these represent the functions or areas where actions or events must take place to ensure the success of procurement procedures or the performance of an organization (Butler \& Fitzgerald, 1999).

Thai et al. (2009) identified the main critical success factors for public procurement: organizational alignment (through close placement of the procurement function in organization) and leadership, organizing the procurement function so that it operates strategically, clear, strong and ethical executive leadership, effective communication and continuous improvement, empowerment of multifunctional / multidisciplinary evaluation teams, achieving a balance between budgetary control and managerial flexibility and analyzing how the funds for the procurement of products and services were spent in the past.

Electronic procurement (e-Procurement) are purchases that use the internet, that is, information and communication technologies (IT\&C), to perform one or more stages of procurement processes such as: market research, negociation, ordering, receipt and analysis of the procurement made (Croom \& Brandon-Jones, 2004). Cooper \& Zmud (1990) proposed for easier implementation, that the adoption of IT applications (including e-Procurement) should be done in five stages: initiation, adoption, acceptance, routinization and administration.

Vaidya, Sajeev \& Callender (2004) identified critical success factors for implementing electronic procurement (e-procurement), as follows: the adoption by users and suppliers, project management, system integration, security and authentication, redesigning the process, measuring performance, support given by top management, identification and management of key stakeholders, evaluation of the impact of electronic procurement and the strategy for implementing electronic procurement: good and verified procurement practices, opportunities for aggregation / centralization, consistent approach to relationships with industry and small firms.

In order to successfully implement electronic procurement, human factors play a much more important role than technological factors, the succes of implementation being given by the level of user satisfaction (contracting authorities and economic operators) (Vaidya, Sajeev \& Callender, 2006).

Regarding the electronic procurement (e-Procurement), DiGrande et al. (2013) consider that external factors are external forces in the organization environment, such as improving efficiency and Rogers (2003) stated that external factors force managers to take efficient and rapid decisions for the survival and growth of the business and to adopt IT\&C innovations. External factors can be interpreted as catalysts, preconditions that motivate and trigger the adoption of e-Procurement (Cragg \& Mills, 2011; Nguyen, 2009).

Minahan \& Degan (2001), Eadie et al. (2007) and Fernandes \& Vieira (2015), analyzed the external factors that influence the success of the adoption of e-Procurement in the USA. The mentioned authors identified the following external factors: government support, transaction and payment cost, organizational culture, number of suppliers / providers, confidence in the supply chain and improved competition. 
Following the analysis of qualitative data, Altayyar \& Kerridge-Beaumont (2016), identified the following key external factors that influence the adoption of e-Procurement in Saudi Arabia: government support (the most important factor), the existence of reliable online payment options, the existence of reliable delivery services, high speed internet connection, with low costs, the skilled labor force, procurement officers and representatives of economic operators well trained, suppliers pressure, competition pressure, the existence of policies and regulations, country culture and business environment.

Vatalis, Manoliadis \& Mavridis (2012) have identified performance indicators (PI) for green public procurement in Greece in the construction sector. These are: waste reduction (the most important indicator in terms of sustainability), customer satisfaction, personnel training, capacity utilisation, services and quality, cooperation with customers and the use of technology.

The challenges and barriers for the implementation of the e-Procurement in the construction industry in developing countries have been analyzed from several perspectives by Tran, Huang, Liu \& Ekram (2011). In the authors' view, the most important barriers and challenges are:

- technological perspective: security of data and information transactions, finding a suitable and accesible technical solution, cost of investment, lack of system integration, lack of standardization, problems with system compatibility, specifications of construction works insufficiently described;

- management perspective: development of trust in new technologies, cooperation and long-term relationships with customers, lack of qualified personnel, lack of leadership, lack of commitment from top management, complexity of acquisitions, lack of system knowledge, lack of strategic management, lack of clear vision and objectives;

- organizational perspective: changing the way of thinking, complex hierarchical structure, characteristics of unique projects, lack of resources, different organizational cultures;

- environmental perspective: lack of IT\&C policies regarding e-Procurement, lack of an efficient legal (regulatory) system, poor IT infrastructure, lack of availability of suppliers, reluctance to share data with business partners, lack of customer demands, lack of pressure from competitors (Tran, Huang, Liu \& Ekram, 2011).

Also, Wondimu et al. (2016) identified and analyzed the success factors for the early involvement of the contractors (builders) in public infrastructure projects. Early involvement refers to involvement and contribution of the contractors at an early stage of development of the infrastructure projects, buyers receiving asisstance in project planning. Because the buyer works with the builder, the project owner and the consultant, early involvement has the following three major benefits: improves the relationships, increases the level of understanding between the parties involved and reduces adverse relationships. The success factors identified by the mentioned authors for early involvement of the contractors in infrastructure projects are: the timing of the application of these factors, meaning the involvement of the builders early enough, the equitable distribution of risks between the contracting authority and the winning bidder, the competence of the purchasers and of the structures within the contracting authority that establish the technical specifications, adequate compensation for the manufacturers' contribution, the qualification of the bidders, meaning the acceptance of the bidders who have similar experience in carrying out projects similar to the one that is the object of the procurement procedure and the trust between the project owner and contractor (Wondimu et al., 2016). 


\section{Research methodology}

The research methodology consists of studying the literature in the field, analyzing the data from the official statistics published by ANAP, analyzing the field of public procurement and the views issued by the specialists in the field in order to identify the characteristics of the environment in which public procurement in Romania is carried out, the stakeholders and critical success factors.

The use of information from official statistics published by ANAP presents the advantages of being accurate and relevant data, extracted from the Romanian Electronic Public Procurement System (SEAP), data covering the entire territory of Romania.

\section{Results and discussions}

\section{The environment of public procurement in Romania}

The Romanian environment in which public procurement is carried out is characterized by the existence of a large number of legislative provisions that are frequently modified. Laws governing the field of public procurement are very complex and transpose European directives into national law. The complexity of the legislation and the large number of legislative changes cause the increase of the duration of evaluation and syncope regarding the conduct of the procurement procedures, their cancellations, the receipt of a large number of requests for clarifications, etc.

For example, in Romania in 2018 the average time for the conduct of procedures was 95 days for the procedures that were not verified ex-ante by the National Agency for Public Procurement (ANAP) and 143 days for the procedures verified ex-ante by ANAP and the number of appeals was 2,274 appeals to a number of 18,643 procurement procedures, meaning a weight of 12.19\% (ANAP, 2019).

The results of the appeals resolution are presented in Table 2.

Table 2. The results of the appeals resolution

\begin{tabular}{|c|c|c|}
\hline The results of the appeals resolution & Number of appeals & Weight \\
\hline Cancellation of the procurement procedure & 80 & $3.52 \%$ \\
\hline Provision of remedial measures & 1,011 & $44.46 \%$ \\
\hline Rejection of appeals & 1,183 & $52.02 \%$ \\
\hline TOTAL & $\mathbf{2 , 2 7 4}$ & $\mathbf{1 0 0 \%}$ \\
\hline \multicolumn{2}{|c}{ Source: (ANAP, 2019) }
\end{tabular}

A positive aspect is the existence of a software application specially dedicated to public procurement, which is called Electronic Public Procurement System (SEAP), which ensures the transparency of public procurement. The public procurement system is characterized by a large number of economic operators. For example, on 31 December 2018 in the Electronic Public Procurement System (SEAP) there were registered 20,773 contracting authorities and 139,206 economic operators. The large number of contracting authorities, the complexity of the legislation, the existence of the dedicated software application and the large number of legislative changes create a big problem regarding the training of the purchasers that must be of high level.

Other positive aspects of the public procurement processes in Romania are: the high share of experienced purchasers, the wide variety of procurement procedures (9 types of procedures), the existence of a national strategy dedicated to the field of public procurement and the execution of Ex-Ante controls of the procurement procedures by the ANAP and ExPost controls by the Romanian Court of Accounts. 
In Romania, Article 8(2) of Government Decision no. 395/2016 sets out the three phases of the procurement process, namely preparation/planning, organization of the procedure and award of the contract and performing and monitoring of the contract.

Figure 1 shows the timing of the Ex-Ante and Ex-Post controls performed by ANAP and Romanian Court of Auditors.

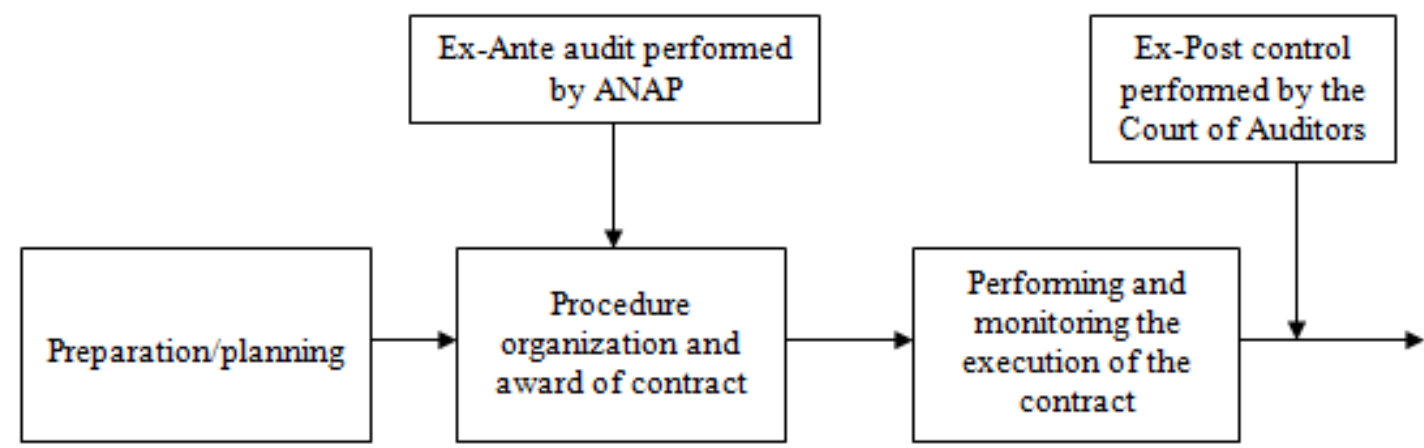

Figure 1. Representation of the timing of Ex-Ante and Ex-Post controls

Source: author's conception

As for the specialized training of the procurers, this is non-unitary. The purchasers are lawyers, economists, teachers, engineers who acquire the knowledge working in the field, without following specialized studies in the field of procurement that follow a clear methodology. The specialists appreciate that the training of personnel in the field of public procurement lasts between 4 and 6 years. There is no central procurement institution in Romania (such institutions exist in states as France, USA, United Kingdom, Australia). The training of the Romanian purchasers is carried out by a series of private companies that organize training courses lasting one week after which they get the title of "Public Procurement Expert", without receiving solid knowledge and skills.

There are no professional degrees in the public procurement system in Romania that reflect the experience and competences of the purchasers, as there is no list of the nationally accepted license fields for practicing this profesion and for promoting the purchasers and the heads of the procurement compartiments. Unfortunately, young people (graduates of higher education) are not attracted to the field of public procurement, on the one hand because of the complexity of the legislation and on the other hand, because of the risks they have to take when practicing this 'job'.

The potential of public procurement is neglected and the procurement function is not organized so as to operate strategically, because:

- the public procurement in Romania was not used to stimulate the economic recovery in the case of the economic crisis of 2009-2010, by allocating additional budgetary funds dedicated to infrastructure works;

- procurement is not used as an instrument of innovation policies to stimulate research and innovation. Following the adoption of a new legislative package in 2016, as a result of the transposition of European directives, a new procurement procedure was introduced in Romania, specifically designed to support innovation, namely the partnership for innovation. Even if this procedure was introduced in the legislation, no such procedure was carried out at national level in 2016-2018.

But the biggest problem in the field of public procurement is corruption. Due to the large amounts that are spent annually, the complexity of the procedures and the summary 
controls, Romania presents a high risk of corruption. Romania is one of the states with high risks in the field of public procurement and a high degree of corruption, along with countries such as Italy, Czech Republic and France (IJC, 2015). According to the report prepared by the European Commission (2014) following a survey carried out between February and March 2013, 91\% of those surveyed in Romania considered that the level of corruption was high (above the European average of $75 \%$ ) and $82 \%$ considered that bribery and the use of relationships is the easiest way to obtain public procurement contracts or public services.

\section{Stakeholders involved in the public procurement process in Romania}

Many stakeholders are involved in the process of public procurement in Romania: contracting authorities, suppliers / providers, regulatory authorities, authorities for resolving the appeals, citizens, various taxpayers, representatives of the state including elected officials, managers, etc.

Within the public procurement system in Romania we find the following stakeholders:

- the contracting authorities, acting as purchasers are represented by various central or local public administration authorities;

- the economic operators, which can be any supplier or contractor offering for sale products, services or works. The contracting authorities and suppliers are the two main actors involved in the conduct of public procurement;

- the national public procurement regulatory authority, respectively the Romanian National Agency for Public Procurement (ANAP), which implements the government's policy in this area, seeks to implement the legislation adopted, drafts proposals for new or amended legislation, carries out Ex-Ante controls of award procedures and impose sanctions;

- other public procurement system supervisors:

- the National Council for Solving the Appeals (CNSC), an institution that solves the appeals that have been submitted by some economic operators following the conduct and completion of the procurement procedures;

- the Romanian Court of Auditors, which is the institution that has control over the use of the financial resources of the Romanian state and the public sector. Also, the Romanian Court of Auditors carries out Ex-Post controls of award procedures;

- the courts, with alternative jurisdiction established by Law no. $101 / 2016$, with regard to the settlement of any appeals or disputes resulting from the conduct of the procurement procedures.

- public procurement takes place in Romania through the Electronic System for Public Procurement (SEAP), a system that is operated by the Romanian Agency for The Digital Agenda, which is directly subordinated to the Romanian Prime Minister.

\section{Critical success factors for public procurement in Romania}

In the author's opinion, the critical success factors for public procurement in Romania are:

- government support, meaning support provided by the political factor;

- the qualification and competence of the purchasers. A well-trained and motivated body of purchasers is an element that can make a decisive contribution to the success of the procurement process. The motivation can be obtained by establishing a system of awarding of the purchasers / specialists in the field and introducing a system of professional degrees;

- competition in procurement procedures. Increased competition within the procurement procedures (by stimulating the increase of the number of companies that register 
in the Electronic Public Procurement System - SEAP) will lead to lower prices and implicitly additional savings to the state budget;

- legislative stability;

- electronic procurement. Adapting / extending electronic procurement to existing legislation and realities must be done continuously;

- analysis of the funds spent. Analyzing how the budgetary funds were spent should be done to increase the efficiency of the procurement process and identify opportunities to obtain additional discounts based on the quantities purchased separately during a year;

- the equitable distribution of risks within a procurement procedure between the contracting authorities and the participating economic operators;

- the improvement of the cooperation between the purchasers and stakeholders;

- analysis of justification of existence of the procurement compartments on efficiency and cost-effectiveness criteria, which may lead to the reduction of the number of contracting authorities at local level. In many states of Europe, the localities that have a number of inhabitants or a budget below a certain threshold cannot have public procurement compartments because they are no longer justified by the high operating costs compared to the spent budgets.

As regards the competition within the procurement procedures in Romania in 2018, the average number of offers received for each type of procedure is presented in Figure 2.

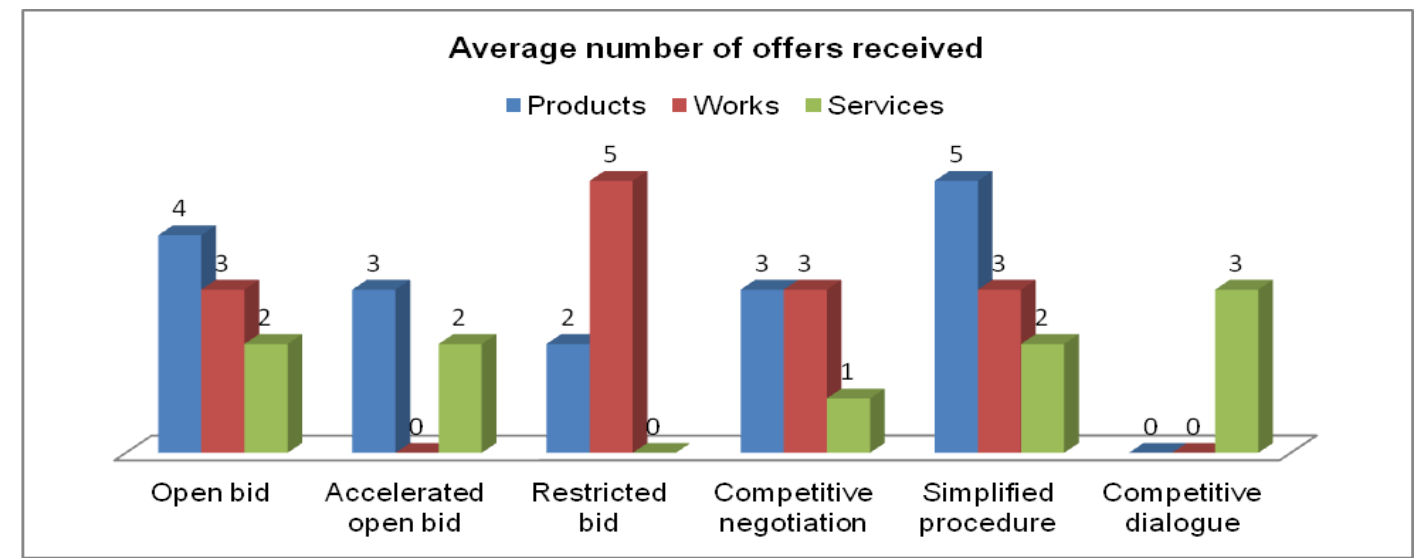

Figure 2. The average number of offers received for each type of procedure in Romania in 2018

Source: (ANAP, 2019)

As can be seen from Figure 2, the highest number of offers was received in simplified procedures and the lowest number of offers was received for service contracts.

\section{Conclusions}

The article identifies and analyzes the most important characteristics of the environment, stakeholders and critical success factors in the field of public procurement in Romania. Research shows that the public procurement environment is characterized by the existence of a large number of legislative provisions, the existence of a specially dedicated IT application for public procurement, the large share of experienced purchasers, the wide variety of procurement procedures, execution of Ex-Ante and Ex-Post controls of procurement procedures, non-unified training of purchasers, lack of a system of professional degrees for purchasers, the most important problem being corruption. 
The main stakeholders in the field of public procurement are: contracting authorities, economic operators, national regulatory authority (ANAP), Romanian National Council for Solving the Appeals (CNSC), Court of Auditors, courts and the Romanian Agency for the Digital Agenda. The most important critical success factors identified are: government support, qualification and competence of purchasers, competition in procurement procedures, legislative stability, electronic procurement and improved cooperation between purchasers and stakeholders.

\section{References}

Altayyar, A., \& Kerridge-Beaumont, J. (2016). External factors affecting the adoption of eprocurement in Saudi Arabia's SMEs. Procedia - Social and Behavioral Sciences, 229(1), 363-375.

ANAP - National Agency for Public Procurement (2019). Indicatorii de monitorizare a eficienței procedurilor de achiziție publică finalizate prin contract în anul 2018. Retrieved from http://anap.gov.ro/web/wp-content/uploads/2019/09/Indicatori-demonitorizare-2018_final-23Sep2019.pdf.

Butler, T,. \& Fitzgerald, B. (1999). Unpacking the Systems Development Process: An Empirical Application of the CSF Concept in a Research Context. The Journal of Strategic Information Systems, 8(1999), 351-371.

Coggburn, J., D. (2003). Exploring differences in the american states' procurement practices. Retrieved from http://ippa.org/jopp/download/vol3/issue-1/Coggburn.pdf.

Cooper, R., B., \& Zmud, R., W. (1990). Information Technology Research: A Technological Diffusion Approach. Management Science, 36 (2), 123-139.

Cragg, P., \& Mills, A. (2011). IT support for business processes in SMEs. Business Process Management Journal, 17(5), 697-710. In Altayyar A., \& Kerridge-Beaumont, J. (2016). External factors affecting the adoption of e-procurement in Saudi Arabia's SMEs. Procedia - Social and Behavioral Sciences, 229 (2016), 363-375.

Croom, S., \& Brandon-Jones, A. (2004). E-Procurement: Key issues in e-Procurement implementation and operation in the public sector. 13th International Purchasing \& Supply Education \& Research Association (IPSERA) Conference, April 4-7, Catania, Italy. In Vaidya, K., Sajeev, A. S. M. \& Callender, G. (2006). Critical factors that influence e-procurement implementation success in the public sector. Retrieved from http://ippa.org/jopp/download/vol6/issue-1-2/e_ProSympAr6_Vaidya_etal.pdf.

DiGrande, S., Knox, D., Manfred, K.. \& Rose, J. (2013). Unlocking the $\overline{\text { digital-marketing }}$ potential of small businesses BCG Perspectives. Retrieved from https://www.bcg.com/publications/2013/transformation-unlocking-digital-marketingpotential-small-businesses.aspx

Eadie, R., Perera, S., Heaney, G., \& Carlisle, J. (2007). External factors and barriers to public sector e-procurement within Northern Ireland's construction industry. Journal of Information Technology in Construction, 12 (2), 103-120.

European Commission (2014). Businesses' attitudes towards corruption in the EU. Flash Eurobarometer 374, February 2014. Retrieved from http://ec.europa.eu/public_opinion/flash/fl_374_en.pdf.

EC - European Council (2013). Multiannual financial framework for 2014 - 2020. Retrieved from https://www.consilium.europa.eu/en/policies/eu-budgetary-system/multiannualfinancial-framework/mff-2014-2020/.

Fernandes, T., \& Vieira, V. (2015). Public e-procurement impacts in small-and mediumenterprises. International Journal of Procurement Management, 8 (5), 587-607. 
Government Decision (Romanian) no. 395/2016 regarding public procurement.

Grigorescu, A., Lincaru, C., Pirciog, S., \& Chitescu, R.I. (2019). Competitiveness and sustainable development in public services. Management \& Marketing. Challenges for the Knowledge Society, 14(1), 108-129.

Harland, C.M., Callender, G., Knight, L.A., Telgen, J., Thai, K.,V., \& Walker, H. L. (2006). Public procurement as a lever of government reform: international research evidence. In: Proceedings of World Wide Symposium, San Diego, California, 6-8 April, 58-68.

IJC - Inițiativa pentru o Justiție Curată (2015). Achizițiile publice și crima organizată - o analiză la nivel european. Retrieved from https://justitiecurata.ro/achizitiile-publicesi-crima-organizata-o-analiza-la-nivel-european/.

MacManus, S., A. (1996). Designing and Managing the Procurement Process. In Coggburn, J., D. (2003). Exploring differences in the american states' procurement practices. Retrieved from http://ippa.org/jopp/download/vol3/issue-1/Coggburn.pdf.

Man, P., Matejkova, J., Jurcik, R., \& Heidu, R. (2014). The key factors of transparency of the public procurement in the Czech Republic. Procedia Economics and Finance, 12(2014), 379-386.

Minahan, T., \& Degan, G. (2001). Best practices in e-procurement. Boston, Aberdeen Group, The Abridged Report, Retrieved from http:/www.hedgehog.com/resources/eProcurementAbridged.pdf.

NASPO - National Association of State Purchasing Officials (1999). State procurement: Strategic positioning for the 21st century. Retrieved from https://www.naspo.org/Publications/PgrID/8806/PageID/9/PID/8806/.

Nguyen, T., H. (2009). Information technology adoption in SMEs: an integrated framework. International Journal of Entrepreneurial Behavior \& Research, 15(2),162-186.

Rogers, E., M. (2003). Diffusion of Innovations, Retrieved from https://teddykw2.files.wordpress.com/2012/07/everett-m-rogers-diffusion-ofinnovations.pdf

Telgen, J., Harland, C., \& Knight, L. (2012). Public procurement in perspective. Retrieved from

https://www.utwente.nl/en/bms/tms/staff/telgen/scientific\%20journal\%20papers/2007

$\% 20$ IRSPP $\% 20$ Casebook $\% 20$ -

$\% 20 \mathrm{Ch} 2 \% 20$ Public\%20Procurement $\% 20 \mathrm{in} \% 20$ Perspective $\% 20$ (with\%20LK,\%20CH) .pdf.

Thai, K., V. (2001). Public Procurement Re-examined. Journal of Public Procurement, 1(1), $9-50$.

Thai, K. V. et al. (2009). International Handbook of Public Procurement. 2 - 780, Taylor \& Francis Group.

Tran, Q., Huang, D., Liu, B., \& Ekram, H. (2011). A construction entreprise's readiness level in implementing e-procurement: a system engineering assessment model. Systems Engineering Procedia, 2(2011), 131-141.

Vaidya, K., Sajeev, A. S. M., \& Callender, G. (2004). E-Procurement initiatives in the public sector: An investigation into the critical success. The 13th Annual International Purchasing \& Supply Education \& Research Association (IPSERA) Conference, April 4-7, Catania, Italy.

Vaidya, K., Sajeev, A. S. M., \& Callender, G. (2006). Critical factors that influence eprocurement implementation success in the public sector. Retrieved from http://ippa.org/jopp/download/vol6/issue-1-2/e_ProSympAr6_Vaidya_etal.pdf. 
Vatalis, K., Manoliadis, O., G., \&Mavridis D., G. (2012). Project performanceindicators as an innovative tool for identifying sustainability perspectives in green public procurement. Procedia Economics and Finance, 1(2012), 401-410.

Veeke, R.A.F. (1992) (in Dutch), Inkoop: ieder voor zich of één voor ons allen. Tijdschrift voor Inkoop en Logistiek, 10 (1), 14-17

Winter Commission (National Commission on the State and Local Public Service) (1993). Hard Truths/Tough Choices: An Agenda For State and Local Reform. In Coggburn, J., D. (2003). Exploring differences in the american states' procurement practices. Retrieved from http://ippa.org/jopp/download/vol3/issue-1/Coggburn.pdf.

Wondimu, P., A., Hailemichael, E., Hosseini, A., Torp, O., \& Laedre, O. (2016). Succes factors for early contractor involvement (ECI) in public infrastructure projects. Energy Procedia, 96(2016), 845-854. 